\begin{tabular}{r|ll} 
Management & DE & $\begin{array}{l}\text { DE GRUYTER } \\
2017 \\
\text { OPI. 21, No. 2 }\end{array}$ \\
ISSN 1429-9321 & $\mathbf{G}$ & $\begin{array}{l}\text { DOI: } \\
\mathbf{1 0 . 1 5 1 5 / m a n m e n t - 2 0 1 7 - 0 0 0 9}\end{array}$
\end{tabular}

BEATA GLINKOWSKA

\section{Ukrainian companies in Poland - conditions and structure of foreign direct investment}

Beata Glinkowska, Ph.D. University of Lodz Chair of Management

\section{Introduction}

Ukraine is a country directly neighbouring Poland. Its surface is almost double that of Poland and the population is about 10 million more. The core of the economy is agri-food production, which gives a good basis for foreign direct investment (FDI) ${ }^{1}$ in the Polish agri-food market. This is obviously not the only growing industry in Ukraine. The bioand eco-technology industry for the wider agricultural and food industries (agri and animal production) is also rapidly growing.

The aim of the article is an attempt to find an answer to the question about the state of Ukrainian FDI in Poland as well as the basic incentives implemented by the Polish government to attract FDI from the Ukrainian market. The material for analyses and conclusions was collected by: direct tests conducted personally: in 2015 and 2017 in Ukraine (semi-structured interviews);

1 The author acknowledged the essence of foreign direct investment (FDI) to be as defined by the OECD, despite of being aware of the existence of various definitional views in this regard. According to this definition, ,a direct investment enterprise is an entity in which a foreign direct investor holds at least $10 \%$ of the ordinary shares (i.e shares in capital) or entitled to $10 \%$ of voting rights at the General Meeting of Shareholders or otherwise has an effective management effect." [in:] OECD, Benchmark definition of foreign direct investment, Third edition, 1999, p. 7. 
analysis of data from the web pages of Polish and Ukrainian statistical offices; analysis of the literature; analysis of data available on the government and local government websites of Poland and Ukraine. Own empirical research was conducted in: Institute of Industrial Economics of the National Academy of Sciences of Ukraine (evacuated from Donetsk in 2014), Institute of Agricultural Economics of the National Academy of Sciences of Ukraine, Kyiv-Mohyla Business-School conducting direct and indirect cooperation with entrepreneurs, Luhansk Taras Shevchenko National University in Starobielsk, Department of Agriculture-Industrial Development of Kyiv District of State Administration. A total of nine direct interviews was conducted at the above mentioned institutions in Ukraine, with the representatives or staff of these institutions. The interviews conducted were of direct character and are of a great value (as perceived by the author), because they showed the authentic sentiment of Ukrainians towards Poland as a place of investment. The empirical research focused primarily on self-governments and entrepreneurs and their attitude to FDI and economic cooperation with Poland. This research has also attempted to distinguish the motives and barriers in the process of internationalization of Ukrainian organizations. In order to realise the aims of this article, an analysis was conducted on the actions aimed at the development of PolandUkraine cooperation, the state of Ukrainian FDI in Poland, investor sentiment of Ukrainians, motives and barriers for the examined FDI. The author is aware of a limited amount of literature cited, however, the nature of the article and its quantitative framework allowed to quote the sources used for analysis.

\section{Poland's administrative activities for the development of Ukraine's cooperation with Poland}

The agreement concerning the development of bilateral Polish-Ukrainian economic cooperation is an essential element of talks between government representatives of both countries. Although such visits are often accompanied by business representatives, there is still a lack of dominant "voice" of entrepreneurs as to the terms of this cooperation. Administrative actions are at present an essential mechanism to support the development of Polish-Ukrainian economic cooperation at the intergovernmental level. The Polish-Ukrainian Intergovernmental Cooperation Council on Interregional Cooperation is the body responsible for such actions. Commission meetings are held annually, and they include, among other things, a general assessment of the state of bilateral economic cooperation, issues related to the ongoing cooperation between Polish and Ukrainian companies, as well as projects aimed at intensifying this

BEATA GLINKOWSKA 
cooperation. Trade and Investment Promotion Office of the Embassy of the Republic of Poland in Kiev (further referred to as TIPO), which, at the request of interested organizations, intervenes in certain administrative bodies of Ukraine to defend Polish entrepreneurs, mainly in the legal and tax fields. Activities by TIPO of the Embassy of the Republic of Poland in Kiev are undertaken in cooperation with economic self-government organizations and international organizations.

The promotional activities of TIPO of the Embassy of the Republic of Poland in Kiev, which result in fairs, exhibitions, thematic conferences, seminars, industry analyses and studies, are also of great importance. These activities promote Poland for cooperation with Ukraine and "attract" Ukrainian entrepreneurs with their investments to the Polish market. They are supplemented by the initiatives of the Polish-Ukrainian Chamber of Commerce, the Polish Chamber of Commerce, the International Society of Polish Entrepreneurs in Ukraine, the European Business Association, and the American Chamber of Commerce in Ukraine, consisting mainly of obtaining opinions on (among other things) undertaking joint ventures. The International Trade Club Ukraine (TCU), an umbrella organization of Ukrainian embassies accredited to Ukraine, is composed of representatives from 58 countries. TCU is organized in cooperation with the Minister of Economy of Ukraine and its individual regions. The objective of the TCU is to provide impartial information about the economy of Ukraine ${ }^{2}$.

\section{Investment incentives in Poland}

In Poland there is a special Programme for supporting investments of major importance to the Polish economy for years 2011-2023, adopted by the Council of Ministers on July 5, 2011. Support under this program may be granted on the basis of a bilateral agreement, which may be concluded between the Minister of Economy of Poland and a foreign investor. The agreement should detail the terms and conditions for the payment of grants. Beneficiaries may be primarily entrepreneurs who plan to invest in the so-called priority sectors ${ }^{3}$ :

2 Actions for the development of Polish-Ukrainian economic cooperation Działania na rzecz rozwoju polsko-ukraińskiej wspótpracy gospodarczej [in:] https://ukraine.trade.gov.pl/pl/ ukraina/168068,dzialania-na-rzecz-rozwoju-polsko-ukrainskiej-wspolpracy-gospodarczej.html (02.09.2017 - access date).

3 Polish Agency for Investment and Trade, PFR Group [in:] https://www.paih.gov.pl/dlaczego_ Polska/zachety_inwestycyjne (03.09.2017 - access date).

Ukrainian companies in Poland - conditions and structure of foreign direct investment 
- aerial,

- agro-food,

- biotechnology,

- automotive,

- electronic,

- research and development,

- modern services.

Investors who are planning to invest in production in other sectors with minimum eligible costs of PLN 750 million and creating at least 200 new jobs, or minimum eligible costs of PLN 500 million and creating at least 500 jobs, may also apply for investment funds. These are the so-called major investments, which can apply for grants for two purposes: employment and investment. The priority for the holder of funds is Eastern Poland, which makes this region particularly attractive for investors in general, and especially for investors from Ukraine. The Polish Investment and Trade Agency is responsible for preparing the complete investment documentation ${ }^{4}$.

General guidelines for investors wishing to know about the conditions of doing business in Poland are available on the website of the Polish Investment and Trade Agency in the form of an English-language guide "Investor's Guide - Poland. How to do business ", which is updated every year. The latest version comes from January 2017 and is about the year 2016 ${ }^{5}$. The publication contains basic information about Poland, its administrative structure, legal regulations related to the conditions and principles of conducting business activity by foreign entrepreneurs, the banking structure, most important sectors in Poland, as well as incentives to invest. Additionally, on the web pages of PAIH you can find information related to the so-called "Investor law", describing privileged zones for investment (so-called economic zones) and tax reliefs.

Poland does not seem to be a very good place for foreign direct investment (FDI) despite many efforts and various incentives implemented by the institutions. Detailed analysis of UNCTAD investment reports from 2015 places

4 The investment aid granted under the public Programme starts in accordance with the rules for granting public aid in the European Union set out in Guidelines on regional State aid for 2014-2020 (OJ C 209, 23.7.2013, p. 1) and in Commission Regulation (EU) No 651/2014 of 17 June 2014 recognizing certain types of aid compatible with the internal market pursuant to Article 107 and 108 of the Treaty (OJ L 187, 26.6.2014, p.1) (as of July 1, 2014).

5 Investor's Guide - Poland. How to do Business, PAIH, 2016 [in:] http://www.paih.gov.pl/publikacje/ jak_prowadzic_dzialalnosc_gospodarcza_w_polsce (04.09.2017 - access date). 
Poland on a high position (the first 20 countries in terms of FDI inflows - \$ 7.5 billion in investments in 2015 compared to \$ 16 billion in FDI investments in Chile (a country half the size of Poland). In 2016 this position deteriorated even further ${ }^{6}$. Meanwhile, foreign investment means not only attracting foreign capital into Poland but also new jobs, development of regions, new technologies, innovative products, higher GDP, new contacts and knowledge 7 .

\section{Ukrainian foreign direct investment (FDI) in Poland}

Every year on the website of the Polish Investment and Trade Agency the list of the largest foreign investors in Poland is published. The current list includes data from December 2015. Table 1 summarizes basic information on the biggest Ukrainian foreign direct investments in Poland.

Table 1. List of the largest Ukrainian investors in Poland - December 2015

\begin{tabular}{|c|c|c|c|c|c|}
\hline \multicolumn{6}{|c|}{ Ukraine } \\
\hline $\begin{array}{l}\text { Rec. } \\
\text { num }\end{array}$ & $\begin{array}{l}\text { Investor } \\
\text { name }\end{array}$ & $\begin{array}{l}\text { Country of } \\
\text { registration }\end{array}$ & Activities (PKD) & Activities (class) & Corporations \\
\hline 1 & CJSC ZAZ & Ukraine & Manufacturing & $\begin{array}{l}\text { Manufacture of } \\
\text { motor vehicles }\end{array}$ & $\begin{array}{l}\text { Fabryka Samochodów } \\
\text { Osobowych S.A. - } \\
\text { Warszawa }\end{array}$ \\
\hline 2 & Elfa & Ukraine & Manufacturing & $\begin{array}{l}\text { Manufacture of } \\
\text { chemicals and } \\
\text { chemical products }\end{array}$ & $\begin{array}{l}\text { Elfa Pharm Sp. z o.o. } \\
\text { - Chociw Gmina } \\
\text { Widawa }\end{array}$ \\
\hline 3 & $\begin{array}{l}\text { Gdańsk } \\
\text { Shipyard } \\
\text { Group }\end{array}$ & Ukraine & Manufacturing & $\begin{array}{l}\text { Building of ships } \\
\text { and boats }\end{array}$ & $\begin{array}{l}\text { Stocznia Gdańsk SA - } \\
\text { Gdańsk }\end{array}$ \\
\hline
\end{tabular}

6 WorldInvestmentReport,UNCTAD,2017,p.189-210[in:]http://unctad.org/en/PublicationsLibrary/ wir2017_en.pdf (04.09. 2017 - access date).

7 Polityka Insight report: Foreign investment - impact on the economy of Poland in the last quarter century, 2017 [in:] www.research.politykainsight.pl (04. 09. 2017 - access date) and EY Report: Record number of foreign investments in Poland and Europe - new jobs generated by FDI, Warsaw, 23 May 2017 [in:] http://www.ey.com/pl/pl/newsroom/news-releases/news-ey-20170523-rekordowaliczba-inwestycji-zagranicznych-w-polsce-i-europie (05.09.2017 - access date).

Ukrainian companies in Poland - conditions and structure of foreign direct investment 


\begin{tabular}{rl|l|l|l|l} 
& $\begin{array}{l}\text { Industrial } \\
\text { Union of } \\
\text { Donbass } \\
\text { (ISD) }\end{array}$ & Ukraine & Manufacturing & $\begin{array}{l}\text { Manufacture of } \\
\text { basic iron and steel } \\
\text { and of ferro-alloys }\end{array}$ & $\begin{array}{l}\text { ISD Polska Sp. z o.o. - } \\
\text { Warszawa }\end{array}$ \\
\hline 5 & $\begin{array}{l}\text { Milkiland } \\
\text { N.V }\end{array}$ & Ukraine & $\begin{array}{l}\text { Wholesale and } \\
\text { of motor vehicles } \\
\text { and motorcycles }\end{array}$ & $\begin{array}{l}\text { Wholesale of food, } \\
\text { beverages and } \\
\text { tobacco }\end{array}$ & $\begin{array}{l}\text { Milkiland EU Sp. z o. } \\
\text { o. - Warszawa }\end{array}$ \\
\hline $\begin{array}{l}\text { PSA } \\
\text { Iskra" }\end{array}$ & Ukraine & Manufacturing & $\begin{array}{l}\text { Manufacture of } \\
\text { electric lighting } \\
\text { equipment }\end{array}$ & $\begin{array}{l}\text { Fabryka Zarówek } \\
\text { Helios Sp. z o.o. - } \\
\text { Katowice }\end{array}$ \\
\hline
\end{tabular}

Source: own study based on: Inwestorzy zagraniczni w Polsce, PAIH, PFR Group [in:] http:// www.paih.gov.pl/publikacje/inwestorzy_zagraniczni_w_polsce (04.09.2017 - access date)

Table 1 shows that investments are mainly located in large port cities (apart from one in Chociw, which is located in the small municipality of Widawa in the Lodz province). By analysing the complete data contained in the PAIH reports, it can be seen that the largest and most valuable investments are from Germany, Denmark, Austria, France, the Netherlands, Finland, England, Italy and even the USA. Ukraine, as a directly neighbouring country, has few big investments in Poland. The company of the aforementioned countries puts Ukraine at a distant place. When analysing the state of large Ukrainian FDIs in Poland, it can be seen that since December 2014 this condition has not changed in terms of quantity. For a period of an entire year there was not even one big FDI from Ukraine in Poland. By contrast, in December 2013, there were three large Ukrainian FDI in Poland (table 2).

Table 2. List of the largest Ukrainian investors in Poland - December 2013

\begin{tabular}{r|l|l|l|l|l}
\hline \multicolumn{5}{l}{ Ukraine } \\
\hline $\begin{array}{r}\text { Rec. } \\
\text { num }\end{array}$ & $\begin{array}{l}\text { Investor } \\
\text { name }\end{array}$ & $\begin{array}{l}\text { Country of } \\
\text { registration }\end{array}$ & Activities (PKD) & Activities (class) & Corporations \\
\hline & CJSC & Ukraine & Manufacturing & $\begin{array}{l}\text { Manufacture of } \\
\text { motor vehicles }\end{array}$ & $\begin{array}{l}\text { Fabryka Samochodów } \\
\text { Osobowych S.A. - } \\
\text { Warszawa }\end{array}$ \\
\hline
\end{tabular}




\begin{tabular}{|c|c|c|c|c|c|}
\hline 2 & $\begin{array}{l}\text { Gdańsk } \\
\text { Shipyard } \\
\text { Group }\end{array}$ & Ukraine & Manufacturing & $\begin{array}{l}\text { Building of ships } \\
\text { and boats }\end{array}$ & $\begin{array}{l}\text { Stocznia Gdańsk SA - } \\
\text { Gdańsk }\end{array}$ \\
\hline 3 & $\begin{array}{l}\text { Industrial } \\
\text { Union of } \\
\text { Donbass } \\
\text { (ISD) }\end{array}$ & Ukraine & Manufacturing & $\begin{array}{l}\text { Manufacture of } \\
\text { basic iron and } \\
\text { steel and of ferro- } \\
\text { alloys }\end{array}$ & $\begin{array}{l}\text { ISD Polska Sp. z o.o. } \\
\text { Warszawa }\end{array}$ \\
\hline
\end{tabular}

Source: own study based on: Inwestorzy zagraniczni w Polsce, PAIH, PFR Group [in:] http:// www.paih.gov.pl/publikacje/inwestorzy_zagraniczni_w_polsce (04.09.2017 - access date).

In December 2012 there was no large Ukrainian FDI in Poland, and in December 2011 there were 3 of them. The data in Table 2 shows the location of FDIs in cities with airports. Gdańsk also has a seaport. It is also worth noting that these three major investments have survived and developed

\section{Foreign direct investment of Ukraine in total}

The statistics on FDI in Ukraine are inaccurate and not up to date, however, according to the statistics for October 2014, Ukrainian business units have invested around $\$ 7$ billion outside of their country ${ }^{8}$. The largest increase in the number and value of Ukrainian foreign direct investment was in 2008, when Ukraine joined the structures of the World Trade Organization. The Ukrainian state agreed at the time to adopt a series of regulations aimed at facilitating international economic exchange and the opening of the Ukrainian market both to the reception of investors and the exit from the home country with their own investments. Compared to previous years, this was a "leap" in the value of investments by about $70 \% 9$. In addition, the visa facilitation agreement entered into force, as well as the readmission agreement between Ukraine and the European Union. Re-facilitation of visas (the abolition of visas for Ukraine - under certain conditions), were introduced in 2016. In 2012, the State Statistics Service of Ukraine noted the location of Ukrainian FDI in 49 countries, with Cyprus at the first place $(89.6 \%)$, followed by Russia $(4.5 \%)$, Latvia $(1.5 \%)$ and Poland

8 Export Promotion Portal [in:] https://ukraine.trade.gov.pl/pl/ukraina/inwestycje/219547, bezposrednie-inwestycje-zagraniczne-i-atrakcyjnosc-inwestycyjna-obwodu-lwowskiego-. html?pubdate=201612081210 (03. 09. 2017 - access date).

9 Crane K., Larabee F. (2015) [in:] Encouraging Trade and Foreign Direct Investment in Ukraine, Rand Corporation Santa Monika; p. 40.

Ukrainian companies in Poland - conditions and structure of foreign direct investment 
$(0.8 \%)^{10}$. Cyprus is a very attractive place for foreign investment of Ukraine due to the existence of so-called- "Tax haven", characterized by low operating costs there, the existence of many Ukrainian companies in Cyprus, so that financial settlements are really between Ukrainian companies, not between countries.

\section{Trade exchange of Ukrainian companies with Poland as a basis for establishing lasting relations - the basis for FDI}

Trade, or otherwise trade in goods that includes such forms of internationalization as exports or imports, by the letter of law are not considered an FDI, but strategically can be a good for FDIs, so it is useful to analyse the status of this exchange between Ukraine and Poland. In 2015 trade between these countries recorded a significant increase. The Ukrainian Statistical Service, which has the same tasks as the Polish Central Statistical Office, reported an increase in exports of Ukrainian goods to Poland by $11.3 \%$. Their import from Polish entrepreneurs also increased by $15.9 \%{ }^{11}$. For Ukraine, Poland has become the third most important export partner (participation in Ukrainian exports is 6.1\%) with Russia (9.9\%) and Egypt (6.2\%) in the lead. Among import partners, Poland took fifth place (with 6.9\% share in Ukrainian imports), Russia (13.3\%), China (11.9\%), Germany (11\%) and Belarus (about 10\%). See table 3.

Table 3. List of the largest Ukrainian investors in Poland - December 2013

\begin{tabular}{c|c|c|c|c|c|c}
\hline \multirow{2}{*}{ Oblast } & \multicolumn{3}{|c|}{ export to Poland } & \multicolumn{3}{c}{ import from Poland } \\
\cline { 2 - 7 } & $\begin{array}{c}\text { \% in oblast's } \\
\text { export }\end{array}$ & million USD & $\begin{array}{c}\text { compared to } \\
\mathbf{2 0 1 5}(\%)\end{array}$ & $\begin{array}{c}\text { \% in oblast's } \\
\text { import }\end{array}$ & million USD & $\begin{array}{c}\text { compared to } \\
\mathbf{2 0 1 5}(\%)\end{array}$ \\
\hline Vinnytsia & 7,70 & 74,5 & 24,5 & 9,6 & 27,6 & $-10,6$ \\
\hline Volyn & 20,80 & 125,6 & $-4,7$ & 7,8 & 86,5 & 17,4 \\
\hline Dnipropetrovsk & 6,2 & 360,7 & 4,5 & 8,3 & 289,7 & 9,5 \\
\hline Donetsk & 6,9 & 238,2 & 26,6 & 2,7 & 31,3 & 137,5 \\
\hline Zhytomyr & 11,1 & 51,1 & 26,6 & 12,9 & 42,7 & 12,9 \\
\hline Zakarpattia & 5,2 & 60,9 & 1,9 & 5,3 & 46,7 & 12,1 \\
\hline Zaporihzia & 5,9 & 134,9 & 3,9 & 4,4 & 43,7 & $-0,3$ \\
\hline Ivano-Frankivsk & 5,6 & 30,8 & 11,9 & 13,8 & 54,0 & 94,6 \\
\hline Kiev & 2,7 & 47,6 & -9 & 6,8 & 199,1 & 0,2 \\
\hline Kirowohrad & 1,5 & $-6,2$ & $-27,9$ & 4,5 & 8,1 & 184,2 \\
\hline
\end{tabular}

10 Державна служба статистики Українни, Інвестиціi зовнищнъоекономічної діятельності України у 2012 роизі, 2013, p. 2 [in:] www.ukrstat.gov.ua (03.09.2017 - access date).

11 http://zik.ua/rubric/economics (05.09.2017 - access date). 


\begin{tabular}{c|c|c|c|c|c|c}
\hline Luhansk & 11,7 & 50,8 & 12,9 & 3,9 & 14,0 & 48 \\
\hline Lviv & 24,8 & 311,7 & 17,2 & 27,0 & 452,6 & 28 \\
\hline Mykolaiv & 1,9 & 31,4 & 135,1 & 5,0 & 34,2 & 20,6 \\
\hline Odessa & 1,7 & 25,9 & $-25,4$ & 2,8 & 35,2 & 11,4 \\
\hline Poltava & 1,4 & 22,0 & $-11,7$ & 2,6 & 23,4 & 52,1 \\
\hline Rivne & 17,5 & 54,4 & 5,1 & 17,9 & 44,0 & 23,7 \\
\hline Sumy & 1,5 & 7,9 & $-7,8$ & 7,2 & 31,2 & 29,3 \\
\hline Ternopil & 55,4 & 159,1 & 9 & 47,8 & 129,1 & $-7,7$ \\
\hline Kharkiv & 2,1 & 21,2 & 65,7 & 3,1 & 45,6 & 20,8 \\
\hline Kherson & 2,9 & 7,3 & 53,7 & 8,4 & 14,3 & $-3,4$ \\
\hline Khmelnytskyi & 9,8 & 30,9 & $-4,8$ & 11,3 & 36,8 & 48,6 \\
\hline Cherkasy & 8,0 & 37,3 & $-11,2$ & 6,3 & 18,3 & 19,8 \\
\hline Chernivtsi & 5,6 & 6,0 & 3,1 & 12,9 & 11,6 & 3,2 \\
\hline Chernihiv & 3,8 & 16,0 & $-22,5$ & 3,2 & 15,1 & 0,4 \\
\hline City of Kiev & 2,9 & 251,0 & 30,3 & 4,8 & 779,3 & $-2,4$ \\
\hline
\end{tabular}

Source: Portal Promocji Eksportu [in:] https://ukraine.trade.gov.pl/pl/ukraina/wymianahandlowa/232101,wymiana-handlowa-obwodow-ukrainy-z-polska-w-2016-r-.html

(05.09.2017 - access date)

The analysis of the data in table 3 shows that entrepreneurs from the following oblasts are the most active in trade cooperation with Poland: Lvov, Kiev, Donetsk, Tarnopol and Dnepropetrovsk. The least interested in trade in goods with Poland are oblasts: Chernigov, Chernivtsi, Kherson.

\section{Results of the conducted interviews}

Interviews conducted in 2015 and 2017 aimed at showing the investor sentiment of Ukrainian entrepreneurs and self-governments in Ukraine for potential trade, joint projects, foreign direct investment cooperation with Polish entrepreneurs and self-governments. A total of 9 interviews were conducted with representatives of the organizations mentioned in the introduction to this study. A summary of the selected results of the tests is presented in table 4 .

The conducted research shows some fundamental issues. Looking at the barriers, the lack of reliable information on the programs and institutions supporting entrepreneurial activity, the unfavourable political sentiment of both countries and the difficult legal and political situation in Ukraine are all piling on top of the lack of support for entrepreneurs (especially micro and small enterprises) by the governments of both countries. In addition, not all The conducted research shows some fundamental issues. Looking at the barriers, 
Table 4. Investor's attitude to Ukraine for cooperation and FDI in Poland

\begin{tabular}{|c|c|c|c|c|}
\hline $\begin{array}{l}\text { Organisa- } \\
\text { tion }\end{array}$ & $\begin{array}{l}\text { Motives of } \\
\text { internationalization of } \\
\text { Ukrainian companies (in } \\
\text { Poland) }\end{array}$ & $\begin{array}{l}\text { Barriers for } \\
\text { internationalization of } \\
\text { Ukrainian companies (in } \\
\text { Poland) }\end{array}$ & $\begin{array}{l}\text { Knowl- } \\
\text { edge } \\
\text { about } \\
\text { support } \\
\text { pro- } \\
\text { grammes }\end{array}$ & Engagement \\
\hline $\begin{array}{l}\text { Luhansk } \\
\text { Taras } \\
\text { Shevchen- } \\
\text { ko } \\
\text { National } \\
\text { University } \\
\text { in Staro- } \\
\text { bielsk }\end{array}$ & $\begin{array}{l}\text { - Increasing company } \\
\text { revenue } \\
\text { - Getting higher profit } \\
\text { margin } \\
\text { - Desire for quick earnings } \\
\text { - Desire to develop } \\
\text { - Existence of favourable } \\
\text { legislation, especially } \\
\text { in economic zones in } \\
\text { Poland } \\
\text { - Cultural proximity and } \\
\text { knowledge of the foreign } \\
\text { market } \\
\text { - Direct neighbourhood } \\
\text { - Connections with } \\
\text { appropriate people from } \\
\text { abroad } \\
\text { - Prestige } \\
\text { - Using advanced } \\
\text { technologies } \\
\text { - Political, legal and } \\
\text { economic instability of } \\
\text { Ukraine } \\
\text { - Unclear legislation } \\
\text { of the country and } \\
\text { small development } \\
\text { opportunities for small } \\
\text { businesses in Ukrainian } \\
\text { market }\end{array}$ & $\begin{array}{l}\text { - No solid co-operator } \\
\text { - Fear of making mistakes } \\
\text { related to documentation } \\
\text { or law } \\
\text { - Lack of direct access to } \\
\text { markets } \\
\text { - Fear of insufficient quality } \\
\text { of own products } \\
\text { - High cost of handling } \\
\text { complaints } \\
\text { - Communication problems } \\
\text { and language barriers } \\
\text { - Lack of capital (especially } \\
\text { by micro and small } \\
\text { businesses) } \\
\text { - Lack of state support and } \\
\text { information on the Polish } \\
\text { market } \\
\text { - No information on the } \\
\text { existence of support } \\
\text { institutions } \\
\text { - Discrimination } \\
\text { - Lack of government support } \\
\text { - Corruption in the Ukrainian } \\
\text { market } \\
\text { - Weak political moods }\end{array}$ & None & $\begin{array}{l}\text { High level of } \\
\text { engagement } \\
\text { in joint } \\
\text { projects }\end{array}$ \\
\hline $\begin{array}{l}\text { Institute of } \\
\text { Industrial } \\
\text { Economics } \\
\text { of NAS of } \\
\text { Ukraine }\end{array}$ & See above & $\begin{array}{l}\text { See above } \\
\text { and: no information on joint } \\
\text { projects }\end{array}$ & $\begin{array}{l}\text { Low level } \\
\text { of knowl- } \\
\text { edge }\end{array}$ & $\begin{array}{l}\text { High level of } \\
\text { engagement } \\
\text { in joint pro- } \\
\text { jects }\end{array}$ \\
\hline
\end{tabular}




\begin{tabular}{|c|c|c|c|c|}
\hline $\begin{array}{l}\text { Depart- } \\
\text { ment of } \\
\text { Agri- } \\
\text { cultural } \\
\text { Economics } \\
\text { of NAS of } \\
\text { Ukraine }\end{array}$ & See above & $\begin{array}{l}\text { See above } \\
\text { and: no information on joint } \\
\text { projects }\end{array}$ & $\begin{array}{l}\text { Low level } \\
\text { of knowl- } \\
\text { edge }\end{array}$ & $\begin{array}{l}\text { High level } \\
\text { of engage- } \\
\text { ment in joint } \\
\text { projects and } \\
\text { implementa- } \\
\text { tions }\end{array}$ \\
\hline $\begin{array}{l}\text { Kyiv- } \\
\text { Mohyla } \\
\text { Business- } \\
\text { School }\end{array}$ & See above & $\begin{array}{l}\text { See above } \\
\text { and: no information on joint } \\
\text { projects }\end{array}$ & $\begin{array}{l}\text { Medium } \\
\text { level of } \\
\text { knowl- } \\
\text { edge }\end{array}$ & $\begin{array}{l}\text { High level of } \\
\text { engagement } \\
\text { in joint pro- } \\
\text { jects, imple- } \\
\text { mentations } \\
\text { and FDI }\end{array}$ \\
\hline $\begin{array}{l}\text { Depart- } \\
\text { ment of } \\
\text { Agri- } \\
\text { culture- } \\
\text { Industrial } \\
\text { Devel- } \\
\text { opment } \\
\text { of Kiev } \\
\text { Oblast }\end{array}$ & See above & $\begin{array}{l}\text { See above } \\
\text { and: lack of organizational } \\
\text { ability of the Polish } \\
\text { government and possible } \\
\text { political aversion }\end{array}$ & $\begin{array}{l}\text { Medium } \\
\text { level of } \\
\text { knowl- } \\
\text { edge }\end{array}$ & $\begin{array}{l}\text { Medium } \\
\text { level of en- } \\
\text { gagement } \\
\text { for coopera- } \\
\text { tion, turno- } \\
\text { ver and FDI }\end{array}$ \\
\hline
\end{tabular}

Ukrainian institutions show great support for close cooperation and openness to cooperation. Respondents have expressed concerns about the excessive expansion of other countries, including Poland, into the Ukrainian market. They are aware of their resources and their potential, also the potential of Ukraine as a country and as an economy and believe that it is the other markets that should open up to Ukraine as an economic partner. The respondents want to do foreign direct investment in Poland but expect support in this regard and favourable attitudes. On the other hand, all respondents agree on the motives for internationalization, emphasizing two issues: cultural and territorial proximity, willingness to develop and increase revenues on the one hand, and lack of support (especially for smaller companies) on their own market and legal and political-economic instability, It may be a direct engine of attempts to develop and tighten Ukraine's economic cooperation with Poland. The reason for the economic activity of Ukrainian entrepreneurs on the territory of the Republic of Poland is also conditioned by their growing reluctance towards Russia, perceived as an aggressive and restrictive country towards Ukraine.

Ukrainian companies in Poland - conditions and structure of foreign direct investment 


\section{Conclusion}

Ukraine, due to its territorial and cultural proximity to Poland, is slowly becoming an open country for economic contacts. It is also an open country to the European Union, which was shown by the events of the last few years. Poland is becoming an increasingly attractive country for Ukrainian investors. It is culturally and territorially close to them. It is precisely this intimacy that is the main reason for the development of economic cooperation between Poland and Ukraine. The potential of the two countries in different areas can be complementary. Cooperation with certain districts in Ukraine should also be developed with regard for geographic proximity, resources and a friendly attitude. Interview with Prof. N. Kisili ${ }^{12}$ gave the author of this study the conviction that political or personal trauma cannot and should not matter in modern economy. What really counts is economy and diplomacy. If neighbouring governments do not cooperate on common business opportunities, then other countries will take advantage of it and this will not create the mutual development of "neighbours". For several years there has been an increase in trade turnover between Ukrainian and Polish entrepreneurs and increase in numbers and value of Ukrainian FDI in Poland, yet it is extremely slow and inefficient. Respondents are of the opinion that Ukrainian companies can rely solely on themselves (especially small ones) and have the support neither from their own country nor from Poland. And that fact is emphasized by them. They consider themselves an attractive country for Polish partners. Their agro-food and chemical products rank as one of the best in the world. This is a belief deeply rooted in their nature and patriotism. Above all, they consider insufficient funds to be one of the basic barriers to conducting foreign direct investment in Poland by a company.

\section{Summary}

\section{Ukrainian companies in Poland - conditions and structure of foreign direct investment}

The aim of the article is an attempt to find an answer to the question about the state of Ukrainian FDI in Poland: showing the state, support, government incentives, motives, barriers and investor sentiment. It was possible to reach the target primarily thanks to a thorough analysis of documentation from the websites

12 Department of Agricultural Economics of NAS of Ukraine.

BEATA GLINKOWSKA 
of the State Statistics Service of Ukraine and interviews with representatives of institutions or their employees. The article consists of three main parts: the first is the administrative activity for the development of Ukraine's cooperation with Poland and the existence of "incentives" for FDI from Ukraine; the second part analysed data on Ukrainian FDI in Poland and Ukrainian FDI in total and approximated the state of commodity exchange of Ukrainian companies with Poland as a basis for economic contacts (which may develop into strategic alliances, joint ventures or FDI); the third part presents the results of empirical research on investor sentiment, motives and barriers in this process.

Keywords: internationalization, foreign direct investment, FDI, Ukraine, Poland.

\section{Streszczenie}

Bezpośrednie inwestycje zagraniczne ukraińskich przedsiębiorstw w Polsce- uwarunkowania i struktura

Celem artykułu jest scharakteryzowanie ukraińskich BIZ w Polsce: pokazanie stanu, wsparcia, zachęt rządowych, motywów, barier, nastrojów inwestorskich. Artykuł składa się z trzech zasadniczych części: w pierwszej została przedstawiona działalność administracyjna na rzecz rozwoju współpracy Ukrainy z Polską oraz istnienie "zachęt" dla BIZ z Ukrainy; w części drugiej zanalizowane dane dotyczące ukraińskich BIZ w Polsce i ukraińskich BIZ ogółem oraz przybliżono stan wymiany towarowej przedsiębiorstw ukraińskich z Polską, jako podłoża do kontaktów gospodarczych mogących rozwinąć się w alianse strategiczne, wspólne przedsięwzięcia, czy BIZ; w trzeciej części przybliżono wyniki własnych badań empirycznych dotyczących nastrojów inwestorskich, motywów i barier w tym procesie.

Słowa

kluczowe: internacjonalizacja, bezpośrednie inwestycje zagraniczne, BIZ, Ukraina, Polska.

JEL

Classification: F230

Ukrainian companies in Poland - conditions and structure of foreign direct investment 


\section{Bibliography}

1. Crane K., Larabee F. (2015) [in:] Encouraging Trade and Foreign Direct Investment in Ukraine, Rand Corporation Santa Monika; 40.

2. Actions for the development of Polish-Ukrainian economic cooperation [in:] https://ukraine.trade.gov.pl/pl/ukraina/168068,dzialania-na-rzeczrozwoju-polsko-ukrainskiej-wspolpracy-gospodarczej.html (02.09.2017 access date).

3. http://zik.ua/rubric/economics (05.09.2017 - access date).

4. Investor's Guide - Poland. How to do Business", PAIH, 2016 [in:] http://www.paih.gov.pl/publikacje/jak_prowadzic_dzialalnosc_ gospodarcza_w_polsce (04.09.2017 - access date).

5. Foreign investors in Poland, PAIH, PFR Group [in:] http://www.paih. gov.pl/publikacje/inwestorzy_zagraniczni_w_polsce (04.09.2017 - access date).

6. OECD, Benchmark definition of foreign direct investment, Third edition, 1999.

7. PAIH, PFR Group [in:] http://www.paih.gov.pl/publikacje/inwestorzy_ zagraniczni_w_polsce (04.09.2017 - access date).

8. Polish Investment and Trade Agency, PFR Group [in:] https:/ / www.paih. gov.pl/dlaczego_Polska/zachety_inwestycyjne (03.09.2017 - access date).

9. Export Promotion Portal [in:] https://ukraine.trade.gov.pl/pl/ukraina/ inwestycje/219547, bezposrednie-inwestycje-zagraniczne-i-atrakcyjnoscinwestycyjna-obwodu-lwowskiego-.html?pubdate=201612081210 (03. 09 . 2017 - access date).

10. Export Promotion Portal [in:] https://ukraine.trade.gov.pl/pl/ukraina/ wymiana-handlowa/232101, wymiana-handlowa-obwodow-ukrainy-zpolska-w-2016-r-.html (05.09.2017 - access date).

11. Polityka Insight report, Foreign investment - impact on the economy of Poland in the last quarter century Co przyniosty inwestycje zagraniczne. Wptyw na gospodarke Polski w ostatnim ćwierćwieczu, 2017 [in:] www. research.politykainsight.pl (04. 09. 2017 - access date).

12. EY Report: Record number of foreign investments in Poland and Europe - new jobs generated by FDI, Warszawa, 23 May 2017 [in:] http:/ /www. ey.com/ $\mathrm{pl} / \mathrm{pl} /$ newsroom/news-releases/news-ey-20170523-rekordowaliczba-inwestycji-zagranicznych-w-polsce-i-europie (05.09.2017 - access date).

13. World Investment Report, UNCTAD, 2017, p. 189-210 [in:] http:/ / unctad. org/en/PublicationsLibrary/wir2017_en.pdf (04. 09. 2017 - access date).

14. Державна служба статистики Українни, Інвестиціі зовнишньоекономічної діятельності України у 2012 році, 2013, p. 2 [in:] www.ukrstat. gov.ua (03.09.2017 - access date). 